\title{
Prinsip Kehati-Hatian di Bidang Pengelolaan Lingkungan Hidup dalam Peraturan Daerah Rencana Tata Ruang Wilayah Provinsi Maluku
}

\author{
La Ode Angga \\ Universitas Pattimura \\ laodeangga@yahoo.com
}

\begin{abstract}
Prudential Principle in the Field of Environmental Management in Regional Regulation Spatial Planning of Maluku Province aims to know the essence of prudential principles in Spatial Planning in Maluku Province. This research is a normative juridical research, that is research conducted on legal principles, the value (norm) of concrete law and legal system. The approach used in this research is philosophical approach, conceptual approach, statute approach. The results obtained that the Prudential Principle in Perda RTRW Maluku Province Number 16 Year 2013 is made early prevention, anticipatory prevention, to protection and management of natural resources and environment and spatial arrangement. Philosophical regulation of prudential principles in this Regulation that considering the function of space as a place of human and other living creatures, perform activities, and maintain its survival, basically its availability is not unlimited. In order to realize the safe, convenient, productive and sustainable in spatial planning in Maluku Province, it is necessary to implement a spatial plan that can harmonize the natural and artificial environments capable of realizing the integrated use of natural resources and artificial resources, and can provide protection against Spatial function and prevention of negative impacts on the environment due to space utilization.
\end{abstract}

Keywords: Prudential Principles, Protection of Environmental Management, Regional Regulation Spatial Planning, Maluku Province.

\begin{abstract}
Abstrak
Prinsip Kehati-Hatian di Bidang Pengelolaan Lingkungan Hidup dalamPeraturan Daerah Rencana Tata Ruang Wilayah Provinsi Maluku bertujuan untuk mengetahui hakekat prinsip kehati-hatian dalam Rencana Tata Ruang Wilayah di Provinsi Maluku.Penelitian ini merupakan penelitian yuridis normatif, yaitu penelitian yang dilakukan terhadap azas-azas hukum, kaedah-kaedah hukum dalam arti nilai (norma) peraturan hukum konkrit dan sistem hukum.Pendekatan yang digunakan dalam penelitian adalah pendekaan filosofis (philosophicalapproach), pendekatan konseptual (conseptual approach), pendekatan perundang-undangan (statute approach). Hasil yang diperoleh bahwa prinsip kehati-hatian dalam Perda RTRW Provinsi Maluku No. 16 Tahun 2013 dilakukan pencegahan secara dini, pencegahan antisipatif, kehati-hatian (Prudential Principles) terhadap perlindungan dan
\end{abstract}


pengelolaan sumber daya alam dan lingkungan hidup serta penataan ruang. Filosofis pengaturan prinsip kehati-hatian dalam Perda RTRW Provinsi Maluku bahwa mengingat fungsi ruang sebagai tempat manusia dan makhluk hidup lain, melakukan kegiatan, dan memelihara kelangsungan hidupnya, pada dasarnya ketersediaannya tidak tak terbatas. Berkaitan itu untuk mewujudkan rencana tata ruang wilayah Provinsi Maluku yang aman, nyaman, produktif, dan berkelanjutan perlu dilakukan rencana tata ruang wilayah yang dapat mengharmonisasi lingkungan alam dan lingkungan buatan mampu mewujudkan keterpaduan penggunaan sumber daya alam dan sumber daya buatan, serta dapat memberikan perlindungan terhadap fungsi ruang dan pencegahan dampak negatif terhadap lingkungan hidup akibat pemanfaatan ruang.

\section{Keywords: Prinsip Kehati-hatian, Perlindungan Pengelolaan Lingkungan Hidup, Peraturan Daerah Rencana Tata Ruang Wilayah, Provinsi Maluku.}

\section{Pendahuluan}

Ketentuan Pasal $28 \mathrm{H}$ ayat (1) dan Pasal 33 ayat (3) \& (4) UUD NRI 1945 merupakan norma dasar dalam perlindungan dan pengelolaan sumber daya alam di Indonesia. Pasal $28 \mathrm{H}$ ayat (1) UUD NRI 1945 menyatakan Setiap orang berhak hidup sejahtera lahir dan batin, bertempat tinggal dan mendapatkan lingkungan yang baik dan sehat serta berhak memperoleh pelayanan kesehatan.

Pasal 33 ayat (3) \& (4) UUD NRI 1945 menyatakan:

(3) Bumi dan air dan kekayaan alam yang terkandung di dalamnya dikuasai oleh negara dan dipergunakan untuk sebesarbesarnya kemakmuran rakyat.

(4) Perekonomian nasional diselenggarakan berdasarkan atas demokrasi ekonomi dengan prinsip kebersamaan, efesiensi berkeadilan, dan berkelanjutan, berwawasan lingkungan, kemandirian serta dengan menjaga keseimbangan kemajuan dan kesatuan ekonomi nasional.

Ketentuan tersebutmenjadi landasan filosifis dan yuridis bagi Negara Republik Indonesia dalam rangka pengelolaan sumber daya alam dan lingkungan hidup termaksud di dalamnya penataan ruang.Selanjutnya penguasaan sumber daya alam dan lingkungan hidup diaturdi dalam Pasal 2 dan Pasal 14 ayat (1) UUPA. Di dalam Pasal 2 UUPA menyatakan Bumi, air dan ruang angkasa, termasuk kekayaan alam yang terkandung di 
dalamnya dikuasai oleh negara dan diberikan kewenangan untuk: (1) Mengatur dan menyelenggarakan peruntukkan, penggunaan, persediaan dan pemeliharaan bumi, air dan ruang angkasa : (2) Menentukan dan mengatur hubungan-hubungan hukum antara orang-orang dengan bumi, air, dan ruang angkasa : (3) Menentukan dan mengatur hubungan-hubungan hukum antara orang dan peraturanperaturan hukum yang mengenai bumi, air, dan ruang angkasa. Selanjutnya Pasal 14 ayat (1) UUPA menugaskan kepada Pemerintah dalam rangka sosialisme Indonesia, untuk membuat suatu rencana umum mengenai persediaan, peruntukkan dan penggunaan bumi, air dan ruang angkasa serta kekayaan alam yang terkandung di dalamnya.

Kewenangan negara dalam UUDNRI 1945 sebagai dasar hukum tertinggi memiliki nilai luhur yang dalam pembukaannya disebutkan: Atas berkat Rahmat Allah Yang Maha Kuasa dan dengan didorongkan oleh keinginan luhur, supaya berkehidupan kebangsaan yang bebas, maka rakyat
Indonesia menyatakan dengan ini kemerdekaannya. Kemudian dari pada itu untuk membentuk suatu Pemerintah Negara Indonesia yang melindungi segenap bangsa Indonesia dan seluruh tumpah darah Indonesia dan untuk memajukan kesejahteraan umum, mencerdaskan kehidupan bangsa, dan ikut melaksanakan ketertibaan dunia yang berdasar kemerdekaan kebangsaan, perdamaian yang abadi dan keadilan sosial.

Pada dasarnya setiap norma hukum yang baik harus mengandung 3 (tiga) dasar pokok, yaitu: dasar yuridis, dasar sosiologis dasar filosofis. Dasar yuridis pembentukan Perda RTRW Provinsi Maluku No. 16 Tahun 2013 adalah UUD NRI 1945, UUPA, UUPPLH dan UUPR; sedangkan dasar filosofisnya bahwa Perda RTRW Provinsi maluku dibentuk berdasarkan nilai-nilai Pancasilais, yakni bahwa penataan ruang dan pemanfaatan sumber daya alam harus betul-betul memperhatikan nilai-nilai yang tertuang dalam Pancasila, yaitu nilai Ketuhanan, nilai Kemanusian, nilai Persatuan dan Kesatuan, nilai 
Demokratis, dan nilai Keadilan Sosial. Selain nilai yang terdapat di dalam Pancasila, pengaturan penataan ruang harus pula memperhatikan nilai kemanfaatan, nilai keseimbangan dan nilai kepastian hukum. Dan dasar sosiologisnya adalah adanya kenyataan empiris tentang pemanfaatan ruang oleh masyarakat yang carut-marut, satu dengan lainnya saling tumpang tindih tanpa memperhatikan keamanan, kenyamanan, produktivitas, keberlanjutan dan kelestarian sumber daya alam dan sumber daya lingkungan hidup.

Perlindungan dan Pengelolaan lingkungan hidup termaksud Perda Nomor 16 Tahun 2013 tentang Rencana Tata Ruang Wilayah Provinsi Maluku merupakan upaya terpadu untuk melestarikan fungsi lingkungan hidup yang meliputi kebijaksanaan, penataan, pemanfaatan,

pengembangan, pemeliharaan, pemulihan, pengawasan, dan pengendalian lingkungan hidup (Husni: 81). Upaya terpadu tersebut dapat dilakukan dengan preventif dan juga dapat dilakukan dengan pencegahan dini terhadap perlindungan dan pengelolaan lingkungan hidup dan penataan ruang di Provinsi Maluku.Akan tetapi UUPPLH menghendaki upaya terpadu itu lebih diutamakan secara preventif. Sehubungan hal tesebut UUPPLH di dalam Penjelasan Umum angka 5 menyatakan:

Upaya preventif dalam rangka pengendalian dampak lingkungan hidup perlu dilaksanakan dengan mendayagunakan secara maksimal instrumen pengawasan dan perizinan.Dalam hal pencemaran dan kerusakan lingkungan hidup sudah terjadi, perlu dilakukan upaya represif berupa penegakan hukum yang efektif, konsekuen, dan konsisten terhadap pencemaran dan kerusakan lingkungan hidup yang sudah terjadi. Sehubungan dengan hal tersebut, perlu dikembangkan satu sistem hukum perlindungan dan pengelolaan lingkungan hidup yang jelas, tegas, dan menyeluruh guna menjamin kepastian hukum sebagai landasan bagi perlindungan dan pengelolaan sumber daya alam serta kegiatan pembangunan lain. UndangUndang ini juga mendayagunakan berbagai ketentuan hukum, baik hukum administrasi, hukum perdata, maupun hukum pidana.Ketentuan hukum perdata meliputi penyelesaian sengketa 
lingkungan hidup di luar pengadilan (Non Litigasi) dan di dalam pengadilan (Litigasi).Penyelesaian sengketa lingkungan hidup di dalam pengadilan meliputi gugatan perwakilan kelompok, hak gugat organisasi lingkungan, ataupun hak gugat pemerintah. Melalui cara tersebut diharapkan selain akan menimbulkan efek jera juga akan meningkatkan kesadaran seluruh pemangku kepentingan tentang betapa pentingnya perlindungan dan pengelolaan lingkungan hidup demi kehidupan generasi masa kini dan masa depan.

Sedangkan yang dimaksud dengan prinsip kehati-hatian bisa dilihat dalam Penjelasan Pasal 2f UUPPLH tersebut menyatakan:

"Bahwa ketidakpastian mengenai dampak suatu usaha dan/atau kegiatan karena keterbatasan penguasaan ilmu pengetahuan dan teknologi bukan merupakan alasan untuk menunda langkah-langkah meminimalisasi atau menghindari ancaman tehadap pencemaran dan/atau kerusakan lingkungan hidup".

Berdasarkan latar belakang tersebut di atas dapat dirumuskan permasalahan:
Apa Hakekat Prinsip Kehati-Hatian Dalam Perlindungan Dan Pengelolaan Lingkungan Hidup Di Bidang Peraturan Daerah Rencana Tata Ruang Wilayah Provinsi Maluku?

\section{Metode Penelitian}

Penelitian ini merupakan penelitian normatif, yaitu penelitian yang dilakukan terhadap azas-azas hukum, kaedah-kaedah hukum dalam arti nilai (norma) peraturan hukum konkrit dan sistem hukum (Sudikno Mertokusumo, 2009 :29) .Di dalam penelitian ini menggunakan beberapa pendekatan. Pendekatan-pendekatan yang digunakan dalam penelitian adalah pendekaan filosofis (philosophicalapproach), pendekatan perundang-undangan (statute approach),(Terry Hutchinson, 2002: 55) dan pendekatan konseptual (conseptual approach) (Peter Mahmud Marzuki, 2008 : 93)

\section{Kerangka Teoritik}

\section{1) Teori Negara Kesejahteraan}

Dalam teori negara kesejahteraan (walfare state), tujuan negara 
dipandang sebagai instrumen untuk mencapai tujuan bersama, yaitu kemakmuran dan keadilan sosial bagi seluruh rakyat Indonesia, (CST Kansil dan Chiristine ST. Kansil, 1977: 20). Teori negara kesejahteraan, merupakan perpaduan antara konsep negara dan negara kesejahteraan. Menurut Burkerns, "Negara hukum (rechtsstaat) adalah negara yang menempatkan hukum sebagai dasar kekuasaannya dan menyelenggarakan kekuasaan tersebut dalam segala bentuknya di lakukan di bawah kekuasaan hukum”, sedangkan konsep negara kesejahteraan menurut: "Bagir Manan adalah: "Negara atau pemerintah tidak semata-mata penjaga keamanan atau ketertiban masyarakat, tetapi pemikul utama tanggung jawab untuk mewujudkan keadilan sosial, kesejahteraan umum untuk sebesarbesarnya kemakmuran rakyat"( Aminuddin, 1999: 9).

Teori Negara Kesejahteraan, digunakan dengan argumentasi bahwa, pemerintah sebagai pemegang kekuasaan, memiliki tugasdan tanggung jawab atas kesejahteraan dan pemenuhan hak-hak dasar warga negara tidak dapat diraihnya sendiri. Konsep negara kesejahteraan membutuhkan peran negara untuk memperluas tanggungjawabnya terhadap masalahsosial ekonomi yang dihadapi oleh banyak orang, (Jimly Asshiddiqie, 2006 : 223).

Lahirnya negara kesejahteraan sebagai reaksi terhadap gagalnya konsep negara hukum klasik dan negara hukum sosialis.Kedua konsep dan tipe negara hukum tersebut, memiliki dasar dan bentuk penguasaan negara atas sumber daya ekonomi yang berbeda.Secara teoretik perbedaan itu dilatarbelakangi dan dipengaruhi oleh idiologi atau pahampaham yang dianutnya. Pada negara hukum liberalis klasik dipengaruhi oleh paham liberalisme atau negara hukum klasik sedangkan negara hukum sosialis dipengaruhi oleh paham Marxisme, (Abrar Saleng, 2009: 9).Dalam konteks menjawab Hakekat Prinsip Kehati-Hatian Dalam Perlindungan Dan Pengelolaan Lingkungan Hidup Di Bidang Peraturan Daerah Rencana Tata Ruang 
Wilayah Provinsi Maluku bertujuan untuk mengetahui hakekat prinsip kehati-hatian dalam Rencana Tata Ruang Wilayah di Provinsi Maluku, negara dipandang berkewajibanuntuk mengatur peraturan perundangundangan yang berpihak kepada perlindungan dan pengelolaan lingkungan hidup sesuaidengan konstitusional Republik Indonesia pada Pasal $28 \mathrm{H}$ ayat (1) dan Pasal 33 ayat ayat (3) \& (4) UUD NRI 1945.

\section{2) Ilmu Perundang-undangan}

Penggunaan teori yang kedua dalam penulisan ini adalah ilmu Perundang-undangan.Ilmu Perundangundangan adalah ilmu yang mempelajari seluk beluk yang berkaitan dengan seperangkat peraturan perundang-undangan yang dikaji mengenai teknik, materi muatan, asas-asas, bahasa hukum terhadap perancangan peraturan perundangundangan, karena sebenarnya obyek dari ilmu perundang-undangan adalah merupakan bagian dari ilmu hukum tata negara dalam arti umum, oleh karena itu metode dan pendekatannya tidak jauh berbeda dengan metode dan pendekatan ilmu hukum tata negara.

Menurut B. Hestu Cipto Handoyo Ilmu Perundang-undangan merupakan cabang dari ilmu hukum yang secara khusus objek kajiannya adalah meneliti tentang gejala peraturan peraturan perundangundangan yakni setiap keputusan tertulis yang dikeluarkan oleh pejabat yang berwenang untuk mengatur tingkah laku manusia yang bersifat dan berlaku mengikat umum. Dengan kata lain ilmu perundang-undangan berorientasi kepada melakukan perbuatan dalam hal ini pembentukan peraturan peraturan perundangundangan serta bersifat normatif Ilmu perundang-undangan terbagi:

a) Proses perundang-undangan (gezetsgebungsverfahren):

meliputi beberapa tahapan dalam pembentukan perundangundangan seperti tahap persiapan, penetapan, pelaksanaan, penilaian dan pemaduan kembali produk yang sudah jadi.

b) Metode prundang-undangan (gezetsgebungsmethode): ilmu 
tentang pembentukan jenis norma hukum yang teratur untuk dapat mencapai sasarnannya. Pengacuannya kepada hal-hal yang berhubungan dengan perumusan unsur dan struktur suatu ketentuan dalam norma seperti objek norma, subjek norma, operator norma dan kondisi norma.

c) Teknik perundang-undangan (gezetsgebungstechnic): Teknik perundang-undangan mengkaji hal-hal yg berkaitan dengan teks suatu perundang-undangan meliputi bentuk luar, bentuk dalam, dan ragam bahasa dari peraturan perundang-undangan.

Teori perundang-undangan dalam penulisan ini digunakan sebagaian alisis dengan argumentasi bahwa, peraturan perundang-undangan atau kebijakan yang baik harus mencerminkan keberpihakan pembuat undang-undang yang baikharus terhadap perlindungan dan pengelolaan lingkungan hidup.Alasan penggunaan teori ilmu PerundangUndangan sebagai Middle Range
Theory berdasarkan suatu pemahaman bahwa dalam menjawab merumuskan Hakekat Prinsip Kehati-Hatian Dalam Perlindungan Dan Pengelolaan Lingkungan Hidup Di Bidang Peraturan Daerah Rencana Tata Ruang Wilayah Provinsi Maluku bertujuan untuk mengetahui hakekat prinsip kehati-hatian dalam Rencana Tata Ruang Wilayah di Provinsi Maluku supaya mendapat hasil yang baik dan maksimal.

\section{Hasil dan Pembahasan}

\section{Hakekat Prinsip Kehati-hatian Dalam Penataan Ruang}

Negara Indonesia saat ini sedang melaksanakan pembangunan di segala bidang kehidupan dalam rangka upaya mencapai cita-cita kemerdekaan bangsa Indonesia.Setiap kegiatan dalam rangka mengisi kemerdekaan bangsa Indonesia dan pelaksanaan pembangunan di segala bidang, tentunya harus mempunyai dasar hukum sebagai pijakannya, baik dasar filosofis, yuridis maupun dasar konstitusionalnya. Dasar filosofis diperlukan dalam rangka memaknai 
hakekat dan arti dibalik perencanaan dan pelaksanaan sesuatu kegiatan, apakah kegiatan itu merupakan kegiatan fisik ataupun non-fisik, dalam rangka pelaksanaan pembangunan guna mewujudkan masyarakat yang adil dan makmur. Sedangkan dasar konstitusional diperlukan dalam hal, bahwa segala kegiatan dalam Negara Hukum Indonesia, baik itu berupa kegiatan pembentukan peraturan perundang-undangan maupun kegiatan Perda Rencana Tata Ruang Wilayah Provinsi Maluku, tentunya harus merujuk pada dasar konstitusionalnya agar mempunyai jaminan kepastian hukum dan berkeadilan.

Konsiderans UUPR bagian menimbang menyatakan bahwa Negara Kesatuan Republik Indonesia yang merupakan negara kepulauan berciri Nusantara, baik sebagai kesatuan wadah yang meliputi ruang darat, ruang laut, dan ruang udara, termasuk ruang di dalam bumi, maupun sebagai sumber daya, perlu ditingkatkan upaya pengeloalaannya secara bijaksana, berdaya guna, dan berhasil guna dengan berpedoman pada kaidah penataan ruang sehingga kualitas ruang wilayah nasional dapat terjaga kelanjutannnya demi terwujudnya kesejateraan umum dan keadilan sosial dengan landasan konstitusional UUD NRI 1945.

Secara filosofis bahwa ruang wilayah Negara Kesatuan Negara Republik Indonesia, baik sebagai kesatuan wadah yang meliputi ruang darat, ruang laut, dan udara, termasuk ruang di dalam bumi, maupun sebagai sumber daya, merupakan Karunia ALLAH SWT Kepada Bangsa Indonesia yang perlu disyukuri, dilindungi, dan dikelola secara berkelanjutan untuk sebesar-besar kemakmuran rakyat sesuai dengan amanat yang terkandung dalam Pasal 33 ayat (3) UUD NRI 1945, serta makna yang terkandung dalam falsafah dan dasar negara Pancasila.

Fungsi ruang sebagai tempat manusia dan makhluk hidup lain, melakukan kegiatan, dan memelihara kelangsungan hidupnya, pada dasarnya ketersediannya tidak tak terbatas. Berkaitan dengan hal tersebut, dan untuk mewujudkan ruang wilayah 
nasional yang aman, nyaman, produktif, dan berkelanjutan maka perlu dilakukan penataan ruang yang dapat mengharmonisasi lingkungan alam dan lingkungan buatan, yang mampu mewujudkan keterpaduan penggunaan sumber daya alam dan sumber daya buatan, serta yang dapat memberikan perlindungan terhadap fungsi ruang dan pencegahan dampak negatif terhadap lingkungan hidup akibat pemanfaatan ruang. Keberadaan ruang yang terbatas dan pemahaman masyarakat yang berkembang terhadap pentingnya penataan ruang sehingga diperlukan penyelenggaraan penataan ruang yang transparan, efektif, dan partisipatif agar terwujud ruang yang aman, nyaman, produktif, dan berkelanjutan, guna untuk keberlanjutan lingkungan hidup dari generasi masa kini dan generasi mendatang.

Penataan ruang merupakan kegiataan yang terstruktur dan sistematis dalam rangka upaya menata dan merencanakan persediaan, peruntukkan, penggunaan dan pemanfaatan sumber daya
alam.Dengan adanya penataan ruang, maka persediaan, peruntukkan, penggunaan dan pemanfaatan sumber daya alam (darat, laut/air, dan udara, serta kekayaan alam yang terkandung di dalamnya) dapat direncanakan dengan baik dan benar sehingga pengelolaan dan pemanfaatannya sesuai kepentingan dan harapan bersama semua pemanggu kepentingan dengan baik.Dengan demikian maka, peranan nilai-nilai filosofis dan konstitusional dalam pelaksanaannya pembangunan di segala bidang, baik pembangunan fisik maupun non-fisik sangat penting. Terlebih lagi dalam pembentukan peraturan perundangundangan yang baik yang dapat diterima oleh semua pihak yang akan dijadikan dasar dan pedoman bagi pelaksanaan pembangunan di segala bidang khususnya di bidang lingkungan hidup dan penataan ruang. Nilai-nilai filosofis yang tercermin dalam sila-sila Pancasila merupakan acuan utama, pedoman utama, sebab nilai-nilai filosofis yang terkandung di dalam Pancasila dan UUD NRI 1945 merupakan kristalisasi dari nilai-nilai 
dan kehendak bangsa Indonesia dari sabang sampai marauke. Hubungannya dengan pembentukan Perda RTRW Provinsi Maluku No. 16 Tahun 2013, selain Pancasila sebagai pedoman utama atau acuan utama juga harus berpedoman kepada UUD NRI 1945, UUPPLH dan UUPR. Di dalam Pasal 28H dan Pasal 33 ayat (3) \& (4) UUD NRI mengatur mengenai perlindungan dan pengelolaan sumber daya alam dan lingkungan hidup. Selanjutnya di dalam Pasal 2f UUPPLH dan penjelasannya menganut prinsip kehati-hatian sebgai implementasi dari pengaturan SDA dan lingkungan hidup di atas.

\section{Pancasila Sebagai Dasar Filsafati dan Cita Hukum (Rechtsidee) Bangsa Indonesia dalam Pembentuakan Peraturan Perundang- undangan}

Pancasila yang berarti lima dasar, yaitu: dasar Ketuhanan Yang Maha Esa, dasar Kemanusian Yang Adil dan Beradab, dasar Persatuan Indonesia, dasar Kerakyatan yang Dipimpin Oleh Hikmah Kebijaksanaan Dalam Permusyawaratan/Perwakilan, dan dasar Keadilan Sosial Bagi Seluruh Rakyat Indonesia. Kelima, dasar ini merupakan satu kesatuan yang tak terpisahkan satu dengan yang lainnya.Nilai-nilai yang terkandung di dalam sila pertama meliputi juga nilainilai yang terkandung di dalam sila kedua, ketiga, keempat, dan kelima, demikianlah pula sebaliknya.

Pancasila pada hakekatnya dapat dibedakan atas hakekat Pancasila yang umum universal yang merupakan substansi sila-sila Pancasila, sebagai pedoman pelaksanaan dan penyelenggaran negara yaitu sebagai Dasar Negara yang bersifat umum kolektif serta aktualisasi Pancasila yang bersifat khusus dan konkrit dan dalam berbagai bidang kehidupan. Hakekat sila-sila Pancasila atau substansi Pancasila adalah merupakan nilai-nilai, sebagai pedoman negara adalah merupakan norma, adapun aktualisasinya merupakan realisasi konkrit Pancasila", (Kaelan dan Ahmad Zubaedi, 2007 : 22).

Pancasila dikatakan sebagai dasar filosofi bangsa dan negara mengandung arti bahwa nilai-nilai 
yang terkandung di dalam Pancasila merupakan nilai-nilai filsafati bangsa Indonesia, nilai-nilai yang hidup dan berkembang di kalangan masyarakat bangsa Indonesia. Nilai-nilai yang tertuang di dalam Pancasila merupakan kristalisasi dari nilai-nilai hidup bangsa Indonesia yang religious, selalu menghargai harkat dan martabat, komunalistis, kebersamaan, musyawarah mufakat, dan berkeadilan sosial.

Nilai-nilai yang terkandung di dalam sila pertama sampai dengan sila kelima merupakan cita-cita, harapan, dambaan bagi bangsa Indonesia yang akan diwujudkan dalam kehidupan bersama. Cita-cita bangsa Indonesia yang ingin mewujudkan masyarakat yang tata tentrem, karta raharja, gemah ripah loh jinawi, dengan harapan untuk diwujudkan dalam tingakah laku dan perbuatan masyarakat bangsa Indonesia.

Pancasila sebagai dasar filsafat negara serta sebagai filsafat hidup bangsa Indonesia pada hakekatnya merupakan suatu nilai-nilai yang bersifat sistematis. Oleh karena itu sebagai suatu dasar filsafat maka silasila Pancasila merupakan suatu kesatuan yang bulat, hirarkis dan sistematis. Dalam pengertian inilah maka sila-sila pancasila merupakan suatu sistem filsafat.Oleh karena merupakan suatu sisitem filsafat maka kelima sila bukan terpisah-pisah dan memiliki makna sendiri-sendiri, melainkan memiliki esensi makna yang utuh.

Dasar pemikiran filosofis dari silasila Pancasila sebagai dasar filsafat negara adalah sebagai berikut.Pancasila sebagai filsafat bangsa dan Negara Republik Indonesia, mengandung makna bahwa dalam setiap aspek kehidupan kebangsaan, kemasyarakat serta kenegaraan harus berdasarkan nilainilai Ketuhanan, Kemanusian, Kerakyatan dan Keadilan. Pemikiran filsafat kenegaraan bertolak dari suatu pandangan bahwa Negara merupakan suatu persekutuan hidup manusia atau organisasi kemasyarakatan dalam hidup manusia (legal society) atau masyarakat hukum.”, (Ahmad Zubaedi, 2007 : 25). 
Eksistensi dari nilai-nilai Pancasila ini dalam Negara Kesatuan Republik Indonesia adalah, bahwa negara merupakan suatu organisasi kesatuan bangsa Indonesia yang dibentuk oleh kelompok manusia yang berdasarkan pada kodrat dasar manusia yaitu manusia sebagai makhluk Tuhan Yang Maha Esa, pada hakekatnya bertujuan untuk mewujudkan harkat dan martabat manusia sebagai makhluk yang berbudaya atau makhluk yang beradab, berakhlak yang selalu berusaha untuk mewujudkan persatuan dan kesatuan agar terdapat keserasian dan keharmonisan dalam kehidupan bermasyarakat. Terwujudnya persatuan dan kesatuan dalam suatu negara akan melahirkan rakyat sebagai bangsa yang hidup dalam suatu wilayah negara tertentu, sehingga haruslah mendasarkan pada nilai-nilai bahwa rakyat merupakan satu kesatuan. Dengan adanya persatuan dan kesatuan maka akan mewujudkan suatu persatuan dalam suatu negara yang tangguh. Dengan demikian, maka akan terwujudnya suatu masyarakat yang tabah dan kuat atas dasar kerakyatan dan kemanusian guna mewujudkan nilai keadilan sosial bagi semua manusia, yang selalu menyelesaikan suatu persoalan dengan demokratis, musyawarah dan mufakat yang hakekatnya akan mampu mewujudkan negara yang berkeadilan sosial bagi seluruh rakyat Indonesia.

Nilai-nilai Pancasila sebagai dasar filsafat negara Indonesia pada hakekatnya merupakan sumber dari hukum dasar negara Indonesia. Sebagai sumber hukum dasar, maka Pancasila merupakan suatu hukum dasar dan cita-cita hukum serta citacita moral yang luhur yang oleh pendiri negara yang mewakili seluruh bangsa Indonesia pada tanggal 18 Agustus Tahun 1945 dinyatakan secara yuridis formal sebagai dasar negara. Menurut penjelasan UUD NRI 1945, pembukaan merupakan pokok-pokok yang terkandung dalam pasal-pasal UUD NRI 1945 tersebut.Artinya pasal-pasal di dalam Batang Tubuh UUD NRI 1945 merupakan penjabaran normatif tentang pokok-pokok pikiran yang terkandung di dalam pembukaan UUD NRI 1945.Pokok-pokok pikiran 
itu merupakan suasana kebatinan UUD

NRI 1945 dan merupakan cita hukum yang menguasai konstitusi baik yang tertulis maupun yang tidak tertulis. Dengan demikian semua produk hukum dan penegakkan hukum di Indonesia haruslah didasarkan pada pokok pikiran yang ada di dalam UUD NRI 1945 termasuk pembentukan UUPA, UUPPLH, UUPR maupun Perda RTRW Provinsi Maluku No. 16 Tahun 2013 acuan utamanya adalah Pancasila, UUD NRI 1945. Pancasila itu merupakan cita hukum. Pancasila dapat merupakan penguji kebenaran hukum positif sekaligus menjadi arah hukum positif tesebut untuk dikritalisasikan dalam bentuk norma yang imperatif untuk mencapai tujuan negara. Dari sini dapat dimengerti bahwa cita hukum harus dibedakan dari konsep tentang hukum: yang pertama terletak di dalam ide dan cita, sedangkan yang kedua merupakan suatu kenyataan yang bersumber dari cita tersebut, (Moh.Mahmud MD, 2011 : 52).

Nilai-nilai Pancasila sebagai dasar filosofi negara Indonesia pada hakekatnya merupakan sumber dari hukum dasar negara Indonesia. Sebagai sumber hukum dasar, maka Pancasila merupakan suatu hukum dasar dan cita-cita hukum serta citacita moral yang luhur yang oleh pendiri negara yang mewakili seluruh bangsa Indonesia pada tanggal 18 Agustus Tahun 1945 dinyatakan secara yuridis formal sebagai dasar negara, yang selanjutnya ditentukan lagi di dalam pembukaan UUD NRI 1945 berkedudukan sebagai pokok kaidah negara yang fundamental. Oleh karena itu, maka Pancasila dalam sistem dan struktur hukum Indonesia dikatakan sebagai sumber hukum. Sebagai sumber hukum tentunya, bahwa nilainilai Pacasila mewarnai cita-cita hukum negara Indonesia, dalam arti norma-norma dan nilai-nilai yang terkandung di dalam sistem hukum negara Indonesia harus mencerminkan nilai-nilai Pacasila.

Dari sudut pandang hukum, Pancasila menjadi cita hukum (Rechtsidee) bangsa ini, artinya Pancasila menjadi dasar dan tujuan setiap hukum di Indonesia.Oleh sebab 
itu, setiap hukum yang lahir di Indonesia harus berdasarkan kepada Pancasila yang memuat konsistensi isi mulai dari yang paling atas sampai yang paling rendah hirarkinya. Hukum-hukum di Indonesia juga harus ditujukan untuk mencapai tujuantujuan negara sebagaimana tertuang di dalam pembukaan UUD NRI 1945, (Proseding Sarasehan Nasional, 2011 : 21).

Cita-cita hukum (Rechtsidee) menurut Rudolf Stammler adalah (Rudolf Stammler, 1995 : 129).

"Konstruksi pikir yang mengarahkan hukum pada cita-cita yang diinginkan oleh masyarakat. Citra hukum berfungsi sebagai bintang pemandu (leistrern) untuk mencapai apa yang dicita-citakan. Cita hukum mengandung prinsip yang berlaku sebagai norma bagi keadilan atau ketidakadilan hukum, dengan demikian cita hukum secara serentak memberikan manfaat ganda yaitu dengan cita hukum dapat diarahkan hukum positif menuju hukum yang adil".

Gustav Radbrach mengatakan: $\left({ }^{1}\right.$ Gustav Radbruch dalam Hamid S. Attamimi, 1989 : 309).

"Cita Hukum (Rechtsidee) tidak hanya berfungsi sebagai tolak ukur yang bersifat regulatif yaitu untuk menguji apakah suatu hukum positif adil atau tidak, melainkan sekaligus berfungsi sebagai dasar yang bersifat konstitutif dan menentukan bahwa tanpa cita hukum positif akan kehilangan maknanya sebagai hukum", (M. Koesnoe, 1995 : 80).

M. Koesnoe mengatakan: (M. Koesnoe, 1995 : 80).

"Nilai-nilai Pancasila merupakan falsafah hidup bangsa Indonesia.Dari falsafah hidup tersebut terbentuklah cita hukum (rechtsidee). Karena nilai tersebut memiliki keutamaan dan menjadi cita hukum, maka ia memiliki hakikat imperatif yang mewajibkan. Inilah yang kemudian membentuk konsep hukum yang kategoris. Selanjutnya dikatakan bahwa: "Cita hukum dari alam nilai. Alam nilai itu sendiri merupakan dunia idea-idea tentang apa yang dianggap mulia serta luhur, oleh karena itu bersifat harus yang menuntut penghormatan dan 
ketaatan kepadanya. Dunia nilai-nilai itu kemudian ditangkap, diolah dan diramu oleh falsafah hidup masyarakat hukum. Dari unsur-unsur konsepkonsep ini, ditarik asas-asas hukum", (M. Koesnoe. 1995 : 80).

Moh. Mahfud MD mengatakan, Pancasila dengan fungsi konstitutifnya menentukan dasar suatu tatanan hukum yang memberi arti dan makna bagi hukum itu sendiri sehingga tanpa dasar yang diberikan oleh pancasila itu hukum akan kehilangan arti dan makna sebagai hukum. Sedangkan dengan fungsi regulatifnya pancasila menentukan apakah hukum positif sebagai produk itu adil ataukah tidak adil, (Moh. Mahfud MD, 2011 : 54).

Selanjutnya secara spesifik Stammler mengidentifikasi cita hukum sebagai kemauan yuridis, yaitu kemauan yang mendorong setiap orang untuk membentuk peraturan-peraturan bagi masyarakat dalam hukum positif.Kemauan yuridis merupakan kemauan dasar dan syarat bagi seluruh hukum positif. Kemauan yuridis bersifat transidental yaitu berfungsi sebagai prinsip terakhir dari segala pengertian tentang hukum, (Stammler, 1995 : 246-247)Cita hukum mengandung arti pada hakekatnya hukum sebagai aturan tingkah laku masyarakat berakar pada gagasan, rasa, karsa, cipta dan pikiran dari masyarakat itu sendiri.

Arif Sidharta mengatakan: (Arief Sudharta, $2008:$ 181).

"Cita hukum dibentuk dalam pikiran dan sanubari manusia sebagai produk berpadunya pandangan hidup, keyakinan, keagamaan, dan kenyataankenyataan yang diproyeksikan pada proses pengkaidahan perilaku warga masyarakat yang mewujudkan keadilan, hasil guna dan kepastian hukum. Dalam dinamika kehidupan masyarakat, cita hukum akan mempengaruhi dan berfungsi sebagai asas hukum yang mempedomani (guilding principle), norma kritik (kaidah evaluasi) dan faktor yang memotivasi dalam pembentukan, penemuan, penerapan dan penemuan prilaku hukum. Dengan dirumuskan perilaku hukum akan memudahkan penjabaran ke dalam berbagai perangkat aturan kewenangan dan 
aturan perilaku serta memudahkan terjaganya konsistensi dalam penyelenggaraan hukum”.

Berangkat dari berbagai
pemahaman tantang cita hukum di atas, maka dapat ditarik pengertian bahwa sebagai suatu ukuran yang berisikan nilai-nilai, maka cita hukum tunduk pada falsafah yang mendasarinya.Setiap cita hukum memiliki rumusan nilai yang berbeda. Rumusan nilai cita hukum yang berdasarkan pancasila akan berbeda dengan rumusan nilai cita hukum yang orientasinya liberalisme dan sosialisme. Dengan demikian rumusan cita hukum negara Indonesia yang berdasarkan Pancasila dan UUD NRI 1945 sebagai dasar konstitusionalnya. Ini berarti bahwa cita hukum bangsa Indonesia harus mencerminkan nilainilai Ketuhanan, nilai Kemanusian, nilai Persatuan, nilai Kerakyatan, dan Permusyawaratan, serta nilai Keadilan Sosial bagi seluruh rakyat Indonesia. Bagi bangsa Indonesia falsafah hidup Pancasila merupakan asas kerohanian negara, norma dasar, cita hukum, dan sumber hukum, (M. Noor Syam: VI).
Hamid $S$ Attamimi mengatakan bahwa: (Hamid S. Attamimi: 33).

"Kelima sila dalam Pancasila dalam kedudukannya sebagai cita hukum rakyat Indonesia dalam kehidupan bermasyarakat, berbangsa, dan bernegara secara positif merupakan "bintang pemandu" yang memberikan pedoman dan bimbingan dalam semua kegiatan, memberi isi kepada setiap peraturan perundang-undangan, dan secara negatif merupakan kerangka yang membatasi ruang gerak isi peraturan perundang-undangan tersebut. Terhadap isi peraturan perundang-undangan, sila-sila tersebut baik secara sendiri-sendiri maupun bersama-sama, baik tunggal maupun berpasangan merupakan asas hukum umum".

Pernyataan di atas menunjukan bahwa Pancasila merupakan pedoman yang memberikan arah, member isi bagi setiap pembentukan peraturan perundang-undangan.Ini berarti bahwa nilai-nilai dan norma-norma yang tertuang di dalam berbagai peraturan perundang-undangan bangsa Indonesia harus mencerminkan nilai-nilai luhur Pancasila.

Pancasila selain sebagai cita hukum, juga merupakan norma fundamental negara (Staatsfundamentalnorm), karena itu 
sila-sila Pancasila baik secara sendiri-

sendiri maupun bersama-sama

merupakan norma dasar atau norma yang tertinggi bagi berlakunya semua norma hukum. Dalam kedudukan ini Pancasila disebut juga sebagai sumber hukum. Degan demikian hukum yang dibangun adalah hukum yang berparadigma Pancasila yang berdasarkan pada UUD NRI 1945, yaitu:(Jimly Asshiddiqie: 206-207):

a. Mencerminkan religiusitas Ketuhanan segenap warga negara melalui keyakinan segenap bangsa warga terhadap Tuhan Yang Maha Esa;

b. Mencerminkan prinsip-prinsip humanitas yang berkeadilan dan berkeadaban atau sila kemanusian yang adil dan beradab;

c. Menjamin dan memperkuat prinsip nasionalitas kebangsaan Indonesia melalui sila persatuan Indonesia;

d. Memperkuat nilai-nilai sovereinitas kerakyatan melalui sila kerakyatan yang dipimpin oleh hikmat kebijaksanaan dalaam permusyawaratan perwakilan;

e. Melembagakan upaya untuk membangun solidaritas sosialitas yang berkeadilan sosial bagi seluruh rakyat Indonesia".

Antara sila yang satu dengan sila yang lainnnya merupakan satu kesatuan yang tak dapat dipisahkan, saling menjiwai satu dengan yang lainnya. Sila Ketuhanan mengandung semangat Kemanusian yang adil dan beradab, sila Kemanusian mencerminkan nilai Ketuhanan dan Kemanusian dan mengandung semangat sila Kerakyatan dan Purmusyawaratan, sila kerakyatan dan permusyawaratan mencerminkan nilai sila Persatuan, Kemanusian, dan persatuan, dan mengandung semangat Keadilan Sosial, dan sila Keadilan social mencerminkan nilai sila Ketuhanan, Kemanusian, Persatuan, dan Kerakyatan dan Permusyawaratan. Dengan demikian, maka dalam pembentukan peraturan perundangundangan hendaknya mencerminkan sila-sila Pancasila.Terlebih lagi dikatakan bahwa Pancasila adalah sumber dasar pembentukan hukum di Indonesia.Sebagai sumber hukum, maka peraturan perundang-undangan yang berlaku di negara Indonesia harus mencerminkan nilai-nilai di dalam sila-sila Pancasila.Pancasila menempati posisi yang utama dalam pembentukan hukum negara Indonesia, sehingga jika terdapat adanya 
peraturan perundang-undagan

bertentangan dengan nilai-nilai luhur

Pancasila, maka peraturan perundangundangan itu harus dirubah atau dibatalkan.

Hal ini sesuai dengan pendapat Hans Kelsen dalam teori hirarki peraturan perundang-undangan.Beliau mengatakan bahwa peraturan perundang-undangan yang lebih rendah tidak boleh bertentangan dengan peraturan perundang-undangan yang lebih tinggi. Hal ini sesuai dengan asas hukum (adagium) yang mengatakan "Lex superior derogate legi inferiori". Senada dengan itu Undang-undang No. 12 Tahun 2011 tentang Pembentukan Peraturan Perundang-undangan mengatur dengan jelas tentang hirarki peraturan perundang-undangan sebagai pedoman bagi pembentukan peraturan perundang-undangan negara Indonesia, mulai dari pembentukan Undang-undang sampai pada pembentukan Perda.

Dengan demikian, maka jelas bahwa pembentukan Undang-undang Penataan Ruang harus mencerminkan nilai-nilai fundamental Pancasila dan UUD NRI 1945 sebagai norma dasar (grundnorm). Selanjutnya pembentukan Perda RTRW Provinsi Maluku sebagai peraturan pelaksanakan dari Undang-undang Penataan Ruang tidak boleh bertentangan dengan UUPA, UUPPLH dan UUPR.

\section{Hakekat Prinsip Kehati-Hatian Dalam Perda RTRW}

Sama seperti ruang wilayah negara lain, ruang wilayah negara Indonesia juga merupakan karunia Allah SWT sebagai wadah atau tempat keberlangsungan hidup manusia dan makluk lainnya. Oleh karena itu, manusia diharapkan dapat melindungi dan mengelola ruang wilayah negara tersebut dengan baik dan bertanggung jawab agar secara optimal bermanfaat untuk keberlanjutan dan kelangsungan hidup manusia yang berkualitas. Yang dimaksudkan dengan kehidupan manusia yang berkualitas di sini adalah "kehidupan yang penuh bahagia", yang didasari pada keserasian, keselarasan, dan keseimbangan, baik dalam hidup 
manusia secara pribadi, dalam hubungan dengan manusia lain, dalam hubungannya dengan alam, dan Sang Pencipta. Secara geografis ruang wilayah Indonesia yang terdiri dari ruang daratan, ruang lautan, dan ruang udara beserta seluruh sumber daya alam yang terkandung di dalamnya merupakan aset besar bangsa Indonesia yang harus dimanfaatkan secara terkoordinir, terpadu, dan seefektif mungkin dengan memperhatikan faktor politik, ekonomi, sosial, budaya, pertahanan keamanan, serta kelestarian, pertahanan kemamanan, serta kelestarian kemampuan lingkungan hidup.

Semua pertimbanganpertimbangan tersebut dimaksudkan agar sumber kekayaan bangsa Indonesia itu semaksimal mungkin dapat menopang terlaksananya pembangunan nasional untuk mencapai masyarakat adil dan makmur.Perhatikan peta ruang wilayah Indonesia, ruang wilayah Indonesia berbentuk kepulauan dengan letak dan posisi yang sangat strategis, baik bagi kepentingan nasional maupun internasional.Secara ekosistem kondisi alamiahnya pun sangat khas karena menempati posisi silang di khatulistiwa antara dua benua dan dua samudera dengan cuaca, musim, dan iklim tropis.

Harus disadari bahwa setiap manusia dan makhluk hidup lainnya membutuhkan ruang sebagai wadah dan pusat kegiatannya, sementara ketersediaan wadah dan pusat kegiatan tersebut sangat terbatas dan bahkan tidak pernah bertambah luas, maka pemanfaatan ruang tersebut perlu diatur dengan sebaik-baiknya agar tidak terjadi pemborosan dan penurunan kualitas ruang.Oleh karena itu, kehadiran berbagai kebijakan penataan ruang harus dimaknai sebagai upaya untuk mengatur pemanfaatan ruang berdasarkan besaran kegiatan, jenis kegiatan, fungsi lokasi, kualitas ruang, dan estetika lingkungan.Kebijakan penataan ruang tersebut meliputi ruang wilayah nasional, ruang wilayah provinsi, dan ruang wilayah kabupaten/kota.Masingmasing ruang wilayah tersebut 
merupakan subsistem ruang menurut batasan administrasi belaka, karena secara alamiah ketiga wilayah tersebut merupakan suatu kesatuan dan tidak dapat dipilahpilah. Sebagai satu kesatuan wilayah ruang yang utuh maka dalam kadar-kadar tertentu pengelolaan salah satu bagian (subsistem) jelas akan berpengaruh pada subsistem yang lain, yang pada akhirnya akan mempengaruhi subsistem ruang secara keseluruhan. Oleh karena itu, pengaturan ruang menuntut dikembangkannya suatu sistem keterpaduan sebagai ciri utamanya.Ini berarti perlu adanya suatu kebijaksanaan nasional penataan ruang yang dapat memadukan berbagai kebijaksanaan pemanfaatan ruang.Seiring dengan maksud tersebut, maka pelaksanaan pembangunan, baik di tingkat pusat maupun di tingkat daerah, harus seuai dengan rencana tata ruang yang telah ditetapkan.

Uraian di atas mengisyaratkan bahwa untuk menjamin tercapainya tujuan penataan ruang baik pada tataran perencanaan, pemanfaatan dan pengendalian pemanfaatan ruang dalam satu kesatuan sistem maka diperlukan perangkat peraturan perundang-undangan yang dapat memberi dasar yang jelas, tegas, dan menyeluruh dalam upaya pemanfaatan ruang.Tentu saja Peraturan Perundangundangan tersebut mencermingkan prinsip-prinsip dalam UUPPLH, seperti prinsip kehati-hatian, berkelanjutan dan keterpaduan, sehingga dapat menekan perusakan dan pencemaran lingkungan hidup.

\section{Hakekat Prinsip Kehati-Hatian Dalam Perda RTRW Provinsi Maluku No. 16 Tahun 2013}

Hasil kajian dan analisis terhadap Perda RTRW Provinsi Maluku terdapat nilai-nilai filosofis yang terdapat dalam pengaturan penataan ruang adalah tertuang di dalam Pasal 4 tentang Asas-asas yang menyatakan: Perda Rencana Tata Ruang Wilayah Provinsi Maluku sebagaimana dimaksud dalam Pasal 2 disusun berasaskan: a) Keterpaduan; b) Keserasian, keselarasan dan keseimbangan; c) Keberlanjutan; d) Keberdayagunaan dan keberhasil gunaan; e) Keterbukaan; f) 
Kebersamaan dan Kemitraan; g) Perlindungan yang mengandung nilainilai filosofis.

Pada dasarnya setiap norma hukum yang baik harus mengandung 3 (tiga) dasar pokok, yaitu: dasar yuridis, dasar filosofis, dan dasar sosiologis. Dasar yuridis pembentukan Perda RTRW Provinsi Maluku adalah UUD NRI 1945, UUPA, UUPPLH dan UUPR; sedangkan dasar filosofisnya adalah bahwa Perda RTRW Provinsi Maluku dibentuk berdasarkan nilainilai Pancasilais, yakni bahwa penataan ruang dan pemanfaatan sumber daya alam harus betul-betul memperhatikan nilai-nilai yang tertuang dalam Pancasila, yaitu nilai Ketuhanan, nilai Kemanusian, nilai Persatuan dan Kesatuan, nilai Demokratis, dan nilai Keadilan Sosial. Selain nilai yang terdapat di dalam Pancasila, pengaturan penataan ruang harus pula memperhatikan nilai kemanfaatan, nilai keseimbangan dan nilai kepastian hukum. Dan dasar sosiologisnya adalah adanya kenyataan empiris tentang pemanfaatan ruang oleh masyarakat yang carut-marut, satu dengan lainnya saling tumpang tindih tanpa memperhatikan keamanan, kenyamanan, produktivitas, keberlanjutan dan kelestarian sumber daya alam dan sumber daya lingkungan hidup.

Dari semua asas tersebut, ditinjau secara filosofis, maka (a) asas keserasian, keselarasan, keseimbangan (b) asas keberlanjutan (c), dan asas kepastian hukum dan keadilan yang mengandung nilai-nilai filosofis. Asas keselarasan, keserasian, keseimbangan, adalah bahwa penataan ruang diselenggarakan dengan mewujudkan keserasian antara struktur ruang dan pola ruang, keselarasan antara kehidupan manusia dengan lingkungannya, keseimbangan pertumbuhan dan perkembangan antar daerah serta antara kawasan perkotaan dan kawasan perkotaan dan kawasan pedesaan.

Asas tersebut menghendaki adanya keserasian, keselarasan, dan keseimbangan dari berbagai subsistem dalam perencanaan, pemanfaatan dan pengelolaan ruang, sehingga akan dapat meningkatkan kualitas ruang 
wilayah yang ada. Di dalam Penjelasan Umum angka 5 alinea kedua UUPR dijelaskan sebagai berikut:

"Penataan ruang yang didasarkan pada karakteristik, daya dukung dan daya tampung lingkungan, serta didukung oleh teknologi yang sesuai akan meningkatkan keserasian, keselarasan, dan keseimbangan subsistem. Hal itu berarti akan dapat meningkatkan kualitas ruang yang ada. Karena pengelolaan subsistem yang satu berpengaruh pada subsistem yang laindan pada akhirnya dapat mempengaruhi system wilayah ruang nasional secara keseluruhan, pengaturan penataan ruang menuntut dikembangkannya suatu system keterpaduan sebagai ciri utama. Hal itu berarti perlu adanya suatu kebijakan nasional tentang penataan ruang yang dapat memadukan berbagai kebijakan pemanfaatan ruang. Seiring dengan maksud tersebut, pelaksanaan pembangunan yang dilaksanakan, baik oleh Pemerintah, pemerintah daerah, maupun masyarakat, baik pada tingkat pusat maupun pada tingkat daerah, harus dilakukan sesuai dengan rencana tata ruang yang telah ditetapkan. Dengan demikian, pemanfaatan ruang oleh siapa pun tidak boleh bertentangan dengan rencana tata ruang".

Nilai keserasian, keselarasan dan keseimbangan ini penting diwujudkan dalam penataan ruang karena mengingat bahwa ruang (darat, laut dan udara, serta ruang bawah tanah) adalah merupakan wadah manusia dan makhluk hidup lainnya untuk tempat tinggal, mengembangkan keturunannya, tempat mencari nafkah, tempat memenuhi berbagai kebutuhan hidupnya baik kebutuhan fisik keberlanjutan kehidupannya, dan tempat melakukan berbagai macam aktivitas untuk keberlanjutan kehidupannya, dan pada tanalah manusia akan dikembalikan atau dikuburkan jika sudah meninggal. Di lain pihak ketersediaan dan kemampuan ruang pada dasarnya terbatas, (Arba, 2012 : 128).

Prinsip harmonisasi dan keseimbangan sejalan dengan tujuan hukum menurut teori hukum timur. Teori hukum timur tidak menempatkan "kepastian" tetapi hanya menekankan pada tujuan hukum yaitu: "keadilan adalah keharmonisan, dan keharmonisan adalah kedamaian", (Achmad Ali, 2009 : 212). Menurut teori hukum timur ini, bahwa hukum tidak bertujuan untuk mencapai kepastian hukum, akan tetapi keadilan, akan tetapi keadilan, yaitu keharmonisan dan kedamaian. Dengan 
keadilan akan menciptakan keharmonisan akan mewujudkan kedamaian. Dengan demikian, maka kehidupan bersama akan bisa berjalan dengan baik dengan saling hormat menghormati hak dan kewajiban yang melekat pada masing-masing subyek hukum.

Keharmonisan dalam penyedian, peruntukkan dan penggunaan ruang dan sumber daya alam sangat diutamakan.Penataan ruang dilakukan dalam rangka upaya mengharmonisasikan dan menyeimbangkan antara berbagai kepentingan yang berhubungan dengan tanah dan sumber daya alam sehingga pemanfaatannya tidak saling merugikan satu dengan lainnya.

Asas keberlanjutan adalah bahwa

Perda RTRW Provinsi Maluku diselenggarakan dengan menjamin kelestarian dan kelangsungan daya dukung dan daya tamping lingkungan dengan memperhatikan kepentingan generasi mendatang.Asas ini menghendaki bahwa perencanaan Parda RTRW Provinsi Maluku harus betul-betul memperhatikan kemampuan dan daya dukung sumber daya alam yang tersedia dan lingkungan hidup. Prinsip utamanya adalah bahwa sumber daya alam dan lingkugan hidup yang ada sekarang ini bukan hanya milik kita sekarang saja akan tetapi juga milik anak cucu dan umat manusia yang akan datang. Oleh karena itu pemanfaaatan ruang dan sumber daya alam wajib memperhatikan kelestarian sumber daya alam dan lingkungan dan keberkelanjutan lingkungan hidup.

Sedangkan asas kepastian dan keadilan adalah bahwa Perda RTRW Provinsi Maluku diselenggarakan dengan berlandaskan hukum/ketentuan peraturan perundang-undangan dan bahwa Rencana penataan ruang dilaksanakan dengan mempertimbangkan rasa keadilan masyarakat serta melindungi hak dan kewajiban semua pihak secara adil dengan jaminan kepastian hukum dan keadilan hukum.

Kepastian hukum dan keadilan ibarat dua mata pedang, yang kadangkadang dipersoalkan di kalangan ilmuan hukum, sebab seringkali 
mengutamakan kepastian hukum mengabaikan keadilan, dan sebaliknya mengejar keadilan mengabaikan kepastian hukum. Menegakkan hukum setinggi-tingginya justru mengabaikan keadilan, memperjuangkan penegakkan keadilan, yang sesungguhnya justeru mengabaikan kepastian hukum.Padahal sesungguhnya secara filosofi kedua hal ini adalah tujuan dan fungsi utama hukum itu.

Gustav Radbruch mengatakan: (Gustav Radbruch, 1989 : 135), bahwa berbicara tentang kepastian hukum adalah berbicara tentang bagian dari cita hukum (idée des Recht). Beliau mengatakan, "cita hukum ditopang oleh kehadiran tiga nilai dasar (Grunwerten), yaitu keadilan (Gerechtigkeit), kemanfaatan (Zweckmaeszigkeit) dan kepastian hukum (Rechtssickerkeit)."

Ada empat hal yang berhubungan dengan makna kepastian hukum: (Gustav Radbruch, 1989 : 136), "Pertama, bahwa hukum itu positif, artinya ia adalah perundang-undangan (gesetzliches Rechts).Kedua, bahwa hukum ini didasarkan pada fakta (Tatsachen), bukan suatu rumusan tentang penilaian yang nanti akan dilakukan oleh hakim, seperti kemauan baik," "Kesopanan." Ketiga, bahwa fakta itu harus dirumuskan dengan cara yang jelas sehingga menghindari kekeliruan dalam pemaknaan, di samping juga mudah dijalankan. Hukum positif itu tidak boleh sering diubah-ubah."

Selanjutnya Fuller (1971) juga mengemukakan delapan asas yang harus dipenuhi oleh hukum dan apabila tidak dipenuhi, maka gagahlah hukum sebagai hukum. Kedelapan asas tersebut adalah sebagai berikut:( Gustav Radbruch, 1989: 137),

1) Suatu sistem hukum terdiri peraturan-peraturan, tidak berdasarkan putusan-putusan sesaat untuk hal-hal tertentu,

2) Peraturan tersebut diumumkan kepada publik,

3) Tidak berlaku surat, karena akan merusak integritas sistem,

4) Dibuat dalam rumusan yang dimengerti umum,

5) Tidak boleh ada peraturan yang saling bertentangan, 
6) Tidak boleh menuntut suatu tindakan yang melebihi apa yang bias dilakukan,

7) Tidak boleh sering berubah-ubah,

8) Harus ada kesesuaian antara peraturan dan pelaksanaan seharihari.

Istilah kepastian hukum menurut Anton M. Moelino memiliki makna perangkat hukum suatu negara yang mampu menjamin hak dan kewajiban setiap warga negara yang jika dihubungkan dengan pendapat Soedikno Mertokoesoemo sebagai "perlindungan yustisiabel terhadap tindakan sewenang-wenang, yang berarti seseorang akan dapat memperoleh sesuatu yang diharapkan dalam keadaan tertentu", (Anton M. Moelyono, dan Soedikno Mertokoesoema, 2002 :131-132).

Prinsip keadilan dalam penataan ruang yaitu bahwa penataan ruang harus selalu menjunjung tinggi rasa keadilan agar ruang wilayah yang tersedia dapat dimanfaatkan secara adil untuk memenuhi kepentingan pemerintah maupun masyarakat pada umumnya.Persoalan keadilan, di kalangan ilmuan mempunyai pendapat atau pandangan yang berbeda-beda. Jhon Rawls mengatakan bahwa: (Jhon Rawls, $2006: 3$ ).

"Keadilan sebagai suatu feirness suatu teori keadilan yang menjeneralisasikan dan mengangkat konsep tradisional tentang kontrak sosial ke level abstraksi yang lebih tinggi. Tatanan masyarakat digantikan oleh situasi awal yang melibatkan batasan-batasan prosedural terutama pada argument yang dirancang untuk memunculkan sesuatu persetujuan awal tentang prinsip-prinsip keadilan"

Selanjutnya John Rawls mengatakan:

"Keadilan adalah kebijakan utama dalam institusi sosial, sebagaimana kebenaran dalam sistem pemikiran. Suatu teori betapapun elegan dan ekonomisnya, harus ditolak atau direvisi jika ia tidak benar; demikian juga hukum dan institusi, tidak peduli betapapun efisien dan rapinya, harus direformasi atau dihapuskan jika tidak adil. Setiap orang memiliki kehormatan berdasar pada keadilan sehingga seluruh masyarakat sekalipun tidak bisa membatalkannya. Atas dasar 
ini keadilan menolak jika lenyapnya kebebasan bagi sejumlah orang dapat dibenarkan oleh hal-hal yang lebih besar yang didapatkan orang lain. Keadilan tidak membiarkan pengorbanan yang dipaksakan pada segelintir orang oleh sebagian besar keuntungan yang dinikmati orang banyak. Karen itu, dalam masyarakat yang adil kebebasan warga negara dinggap mapan; hak-hak dijamin oleh keadilan tidak tunduk pada tawar menawar politik atau kalkulasi kepentingan sosial", (John Rawls, $2006: 34)$.

Keadilan sebagai fairness dimulaidengan salah satu pilihan yang sangat umum yang bisa dibuat orang bersama-sama, yakni dengan pilihan prinsip pertama dari konsep keadilan yang mengatur kritik lebih lanjut serta reformasi institusi. Maka, setelah memilih konsepsi keadilan, dapat menganggap bahwa kita memilih suatu konstitusi dan Undang-undang untuk menegakkan hukum, dan lain-lain, kesemuanya sesuai dengan prinsip keadilan sebelumnya disepakati. Keadilan merupakan fairness yang mengandung asas, manusia untuk mencapai kepentingan hendaknya memperoleh kedudukan yang sama pada saat akan memulai aktivitasnya yang merupakan fundamental bagi subyek untuk memasuki perhimpunan yang mereka kehendaki. Keadilan tidak hanya sekedar konsep moral, melainkan mempersoalkan mekanisme pencapaian dan bagaimana hukum turut upaya pencapaian tersebut.

Aristoteles memaknai keadilan sebagai kebajikan yang bersangkutan pada perhubungan dengan manusia. Keadilan dikelompokkan menjadi dua, yaitu keadilan umum dan keadilan khusus, (O. Notohamidjojo, 1998 :

94) Keadilan umum atau keadilan legal yaitu menuntut perbuatan sesuai dengan undang-undang Negara yang harus ditunaikan demi kepentingan umum.Sedangkan keadilan khusus yaitu guna mewujudkan kebijakan seperti kebijaksanaan dan keberanian. Keadilan khusus bukan dikuasai oleh motif sosial, melainkan merupakan ukuran perbuatan dalam perhubungan sesama manusia lain. Ukuran keadilan khusus adalah kesamaan atau 
proposionalitas. Aristoteles membagi 2 (dua) macam keadilan yaitu: keadilan distributif (justitia distributive) dan keadilan kumunikatif (justitia commutative).

Kegiatan penataan ruang sebagai salah satu bagian dari kegiatan, penataan, penyedian, peruntukkan, pemanfaatan, dan penggunaan sumber daya agararia diarahkan untuk menciptakan pemanfaatan ruang yang berkelanjutan dan berwawasan lingkungan yang berlandaskan pada wawasan nusantara dan ketahanan nasional, mengatur pemanfaatan ruang kawasan budidaya secara baik, dan pemanfaatan ruang yang berkualitas. Sasaran akhir dari pemanfaatan ruang secara berkualitas untuk:

1. Mewujudkan kehidupan bangsa yang cerdas, berbudi luhur dan sejahtera;

2. Mewujudkan keterpaduan dalam penggunaan sumber daya alam dan sumber daya buatan dengan memperhatikan keberadaan sumber daya manusia;

3. Meningkatkan sumber daya alam dan sumber daya buatan secara berdaya guna, berhasil guna, dan tepat guna untuk meningkatkan kualitas sumber daya manusia;

4. Mewujudkan perlindungan fungsi ruang dan mencegah serta menanggulangi dampak negative terhadap lingkungan;

5. Mewujudkan keseimbangan kepentingan kesejateraan dan keamanan.

Hal ini selaras dengan pemikiran Thomas Aquina yang mengatakan bahwa "sasaran utama dari pembentukan hukum adalah untuk menjadikan setiap orang, baik sebagai anggota masyarakat maupun sebagai warga negara hidup secara baik. Tatanan hukum itu tidak lain adalah perintah yang berasal dari akal dan kehendak penguasa yang diberikan kepada bawahannya", (Thomas Aquina, dalam E. Sumaryono, 2009: 87).

Hakekat pengaturan prinsip kehati-hatian dalam Perda RTRW Provinsi Maluku No. 16 Tahun 2013 yaitu guna melakukan pencegahan secara dini, pencegahan antisipatif, kehati-hatian

(Precautionary 
Principle) terhadap perlindungan dan pengelolaan sumber daya alam dan lingkungan hidup serta penataan ruang.Filosofis pengaturan prinsip kehati-hatian/asas kehati-hatian dalam Perda RTRW Provinsi Maluku adalah: bahwa mengingat fungsi ruang sebagai tempat manusia dan makhluk hidup lain, melakukan kegiatan, dan memelihara kelangsungan hidupnya, pada dasarnya ketersediannya tidak tak terbatas. Berkaitan dengan hal tersebut, dan untuk mewujudkan rencana tata ruang wilayah Provinsi Maluku yang aman, nyaman, produktif, dan berkelanjutan maka perlu dilakukan rencana tata ruang wilayah yang dapat mengharmonisasi lingkungan alam dan lingkungan buatan, yang mampu mewujudkan keterpaduan penggunaan sumber daya alam dan sumber daya buatan, serta yang dapat memberikan perlindungan terhadap fungsi ruang dan pencegahan dampak negatif terhadap lingkungan hidup akibat pemanfaatan ruang. Penataan ruang merupakan kegiataan yang terstruktur dan sistematis dalam rangka upaya menata dan merencanakan persediaan, peruntukkan, penggunaan dan pemanfaatan sumber daya alam. Dengan adanya penataan ruang, maka persediaan, peruntukkan, penggunaan dan pemanfaatan sumber daya alam (darat, laut/air, dan udara, serta kekayaan alam yang terkandung di dalamnya) dapat direncanakan dengan baik dan benar sehingga pengelolaan dan pemanfaatannya sesuai kepentingan dan harapan bersama semua pihak dengan baik.Dengan demikian maka, peranan nilai-nilai filosofis dan konstitusional dalam pelaksanaannya pembangunan di segala bidang, baik pembangunan fisik maupun non-fisik sangat penting. Terlebih lagi dalam pembentukan peraturan perundang-undangan yang baik yang dapat diterima oleh semua pihak yang akan dijadikan dasar dan pedoman bagi pelaksanaan pembangunan di segala bidang.

\section{Simpulan}

Penataan Ruang adalah merupakan salah satu instrument dari penerapan prinsip kehati-hatian yang 
bertujuan untuk melakukan

pencegahan dini dari sebuah kegiatan.Dengan adanya penataan ruang, maka persediaan, peruntukkan, penggunaan dan pemanfaatan sumber daya alam (darat, laut/air, dan udara, serta kekayaan alam yang terkandung di dalamnya) dapat direncanakan dengan baik dan benar sehingga pengelolaan dan pemanfaatannya sesuai kepentingan dan harapan bersama semua pihak dengan baik.

\section{Daftar Pustaka}

\section{Buku dan Artikel}

Ali, Achmad, (2009) Menguak Teori Hukum (Legal Theory) dan Teori Peradilan (Judicalprundence) Termasuk Interpretasi Undang-Undang (Legisprudence),Jakarta:

Kencana Prenada Media Group.

Arba, (2012) Rencana Tata Ruang Wilayah Yang Berbasis Lingkungan Hidup (Studi Di Provinsi Nusa Tenggara Barat), Malang :Program Doktor Universitas Brawijaya.

Asshiddiqie ,Jimly, (2006) Perihal Undang-Undang di Indonesia, Jakarta : Sekretariat Jenderal dan Kepanitraan Mahkamah
Konstitusi RI.

Attamimi, Hamid S., (1989)Peranan Keputusan Presiden Republik Indonesia Dalam Penyelenggraan Pemerintahan Negara, (Studi Analisis Terhadap Kepres yang berfungsi pengatur dalam Kurun Waktu Pelita-Pelita), Disertasi, Universitas Indonesia.

Hutchinson, Terry, (2002)Reseaching and Writing in Law, Canberra: Lawbook Co.

Kaelan dan Zubaedi, Ahmad, (2007) Pendidikan Kewarganegaraan Untuk Perguruan Tinggi, Yogyakarta, Paradigma

Koesnoe, M., (1995) Perumusan dan Pembinaan Cita Hukum dan Asas-asas Hukum Nasional,Jakarta :Majalah Hukum Nasional, No. 2., BPHN.

Marzuki, Peter Mahmud, (2008)Penelitian

Hukum,Jakarta: Kencana Prenada Media Group.

Mertokusumo,Sudikno,

Penemuan Hukum, Yogyakarta: Liberty

MD, Moh.Mahmud, (2011) Membangun Politik Hukum, Menegakkan Konstitusi, Rajawali Pers, Jakarta. 
Proseding Sarasehan Nasional 2011, (2011) Implementasi Nilai-nilai Pancasila Dalam Menegakkan Konstitusionalitas Indonesia, Kerjasama Mahkamah Konstitusi RI dengan UGM, Yogyakarta,2-3 Mei.

Rahardjo, Satjipto, (2007) Mendudukan Undang-Undang Dasar, Studi Pembahasan dan Optik Ilmu Hukum Umum, Semarang: Badan Penerbit Undip.

Rahardjo, Satjipto, (2006)Hukum Dalam Jagat Ketertiban, Jakarta: UKI Prees.

Rawls, John, (2006) Teori Keadilan, Dasar-Dasar Filsafat Politik Untuk Mewujudkan Kesejahteraan Sosial Dalam Negara (Penterjemah Uzair Fauzan, Heru Prasetyo), Yogyakarta: Pustaka Pelajar.

Stammler, Rudolf, dalam Theo Hujebers, (1995) Filsafat Hukum Dalam Lintasan Sejarah, Yogyakarta.

Stammler, (1995) dalam badan Pembinaan Hukum Nasional dar Masa ke Masa,Jakarta : BPHN Depatemen Kehakiman RI.

Sudharta, Arief, (2008) Konsep Diskriminatif Dalam Prespektif Filsafat Hukum, dalam Butirbutir Pemikiran Hukum Memperingati 70 Tahun Prof.
Dr. Arief Sudharta, Bandung : Refika Adhitama.

Syam, M. Noor, (2000)Penjabaran Filsafat Pancasila Dalam Filsafat Hukum (Sebagai Landasan Pembinaan Sistem Hukum Nasional) Malang :Laboratorium Pancasila IKIP.

\section{Peraturan Perundang-Undangan}

Undang-Undang Dasar Negara Republik Indonesia Tahun 1945.

Undang-Undang No. 5 Tahun 1960 tentang Peraturan Dasar Pokok-Pokok Agraria Lembaran Negara Republik Indonesia Tahun 1960 No. 104, Tambahan Lembaran Negara Republik Indonesia No. 2034.

Undang-Undang No. 26 Tahun 2007 tentang Penataan Ruang, (Lembaran Negara Republik Indonesia Tahun 2007 No. 68, Tambahan Lembaran Negara Republik Indonesia Tahun No. 4739).

Undang-Undang No. 32 Tahun 2009 tentang Perlindungan dan Pengelolaan Lingkungan Hidup, Lembaran Negara Republik Indonesia Tahun 2009 No. 140 Tambahan Lembaran Negara Republik Indonesia No. 5059.

Peraturan Daerah No. 16 Tahun 2013 tentang Rencana Tata Ruang Wilayah Provinsi Maluku 
Tahun 2013-2033, (Lembaran

Daerah Tahun 2013 No. 16). 